\title{
新製品の情報収集に関する調查*1
}

梅沢 修, 福室憲治, 石倉玲子, 宇田和夫, 川上かつみ, 古泉秀夫, 小清水敏昌, 杉浦良一, 南雲清枝, 細田順一, 宮崎康良 ${ }^{* 2}$

東京都病院薬剤師会医薬情報部会*2

\section{New Drug Information Requested by Hospital Pharmacists}

\author{
OSAMU UMEZAWA, KENJI FUKUMURO, REIKo ISHIKURA, \\ KAZUO UDA, KATSUMI KAWAKAMI, HIDEO KOIZUMI, TO- \\ SHIMASA KOSHIMIZU, RYOICHI SUGIURA, KIYOE NAGUMO, \\ JUNICHI HOSODA, and YASUYOSHI MIYAZAKI*2 \\ Drug Information section, Tokyo Hospital Pharmacists Association*2
}

\begin{abstract}
The purpose of this study is to find out what kind of information the pharmacists need most on newly marketed drugs. A questionnaire was sent to hospital pharmacies asking on 78 items (eg, dosage forms and their physicochemical properties, pharmacology, indications, dosage, adverse reactions, storage), as well as on the frequency of need and difficulty in obtaining the information. A total of 114 hospital and clinic pharmacies ans- wered the questions. Major findings : (1) The demand for pharmacological and therapeutic information was strong among pharmacists since the information of such kind is often requested by physicians. (2) The request for information on quality control and storage was also urgent among pharmacists. ${ }^{3}$ (3) Pharmacists prefer summarized data to elaborate, detailed report. (4) They complain of difficulty in obtaining information on bioavailability, drug interaction, stability and incompatibility.
\end{abstract}

新規に発売される医薬品の情報は, 病院に拁けるD I 活動のために必要なものであり, これらの情報は種々の 媒体により伝達されている. しかし医薬品は多くの情報 を有しており，新製品情報の収集に際して，どのような 情報を重点として収集すべきかを把握する必要がある. またこの情報の必要性は情報がどの程度に要求されるか そよっている.

医薬品情報の収集については, 副作用情報, 臨床治験 薬情報, 新製品情報などD I 活動にとって必要と思われ る情報の種類については既に周知されているところであ るが, 新製品に関して収集すべき詳細な情報項目の重要 度と, それらの各項目の実際的な要求の度合についての 報告はない。

ここでは病院，診療所の薬局において，新製品情報収 集に際して，何が必要な情報項目であるか，またその重

*1 日本病院薬剤師会第 5 回関東学術大会 (1975年 8 月, 群馬) 亿て発表.

*2 東京都千代田区外神田 1 丁目 $1-5 ; 1-5$ Sotokanda 1-chome, Chiyoda-ku, Tokyo, 101 Japan
要度とそれらの項目についての情報要求がどの程度ある かについて知ることを目的として, 東京都病院薬㶡師会 英下の病院診療所を対象とする調査を行なった.

\section{方法}

\section{1. 医薬品情報项目の設定}

医薬品に関する情報項目として，名称関する 11 項 目, 物理的化学的事項に関する 13 項目, 製剤に関する 18 項目, 薬理に関する 20 項目, 治療に関する 16 項 目, 管理に関する 11 項目の総計 78 項目を設定した.

\section{2. 医落品情報项目についての畔查}

医薬品情報項目の必要度と要求度に関する調査はアン ケート形式により行ない, 調査票には上記 1. の医薬品 に関する 78 の情報項目それぞれについて

(1)情報の必要度 : 不可欠, あれば便利だがどちらでる よい, 全く不要.

(2)情報を取得する場合の詳細度はどの程度でよいと考 えますか：詳細な資料（原著など）を必要, 要約情報 (パンフレットなど) の資料で可, 資料不要（口答で 可). 
(3)一般に取得困難な情報はどの項目ですか。

(4)情報要求の多い項目: 頻度が高い, 時々要求され る, ほとんど要求されない，のごとくに設問欄を設け， 該当する闌に○印を記入する.

\section{3. 睭亘対象}

調査票は東京都病院薬剤師会央下の370施設に送付し, そのらち 114 施設から回答が得られ，回収率は $30.8 \%$ である. 施設の内訳は, 大学病院 19 , 国公立病院 15 , 一般病院 49, 訅療所 31 施設である.

\section{4. 集計結果の評価}

調査票の各設問欄の回答を集計し，その結果について の評価を，A： $90 \%$ 以上, B : $70 \%$ 以上, C : $50 \%$ 以上, D : $50 \%$ 以下の 4 段階とした.なお, 比率 (\%) は 114 施設に対する割合で示した。

\section{5. 結果についての記載方法}

設問欄を集計した結果の記載は次のごとくにした。

(1)「情報の必要度」の闌については, 不可欠と回答した ものを必要度としてあらわし, その評価と不可欠と回答 した\%を記した。なお，全く不要と回答したものが $5 \%$ 以上の場合には, 必要度の評価欄に*印を付した。

(2)「情報を取得する場合の詳細度はどの程度でよいと考 えますか」の欄については，これを取得情報の詳細度と あらわし, 詳細な資料を必要と回答したものと, 要約情 報の資料で可，とする回答を加えたるのを，資料を必要 とするものとしてこれを必要度であらわし，その評価と 詳細な資料を必要と回答した％を記した。

(3)「情報要求の多い項目」の欄については，これを情報 要求の頻度とあらわし, 頻度が高いと回答したものと時 々要求されると回答したものを加光，これを情報要求が あるむのとして要求度であらわし, その評価と頻度が高 いと回答した％を記した。

表 1 医薬品名称に関する項目

$A:>90 \%, B:>70 \%, C:>50 \%, D:<50 \%, *$ : 全<不要 $5 \%$ 以上

\begin{tabular}{|c|c|c|c|c|c|c|}
\hline & \multirow{2}{*}{ 項 } & \multirow{2}{*}{ 目 } & \multicolumn{2}{|c|}{ 情報の必要度 } & \multicolumn{2}{|c|}{ 情報要求の頻度 } \\
\hline & & & 必要度 & 不可欠\% & 要求度 & 高頻度\% \\
\hline \multicolumn{3}{|c|}{ 日本㯲準商品分類番号 } & C & 58 & $D$ & 13 \\
\hline \multirow[t]{2}{*}{ 商品名 } & ：和名 & & A & 99 & C & 50 \\
\hline & ：洋名 & & $\mathrm{B}$ & 86 & C & 25 \\
\hline \multirow[t]{3}{*}{ 一般名 } & : 和名 & & A & 94 & C & 31 \\
\hline & ：洋名 & & B & 81 & C & 18 \\
\hline & : 命名 & $\left(\begin{array}{l}\text { WHO, USAN } \\
\text { JAN なE゙ }\end{array}\right.$ & D & 35 & $\mathrm{D}$ & 7 \\
\hline \multirow[t]{2}{*}{ 化学名 } & : & & $B$ & 77 & $D$ & 11 \\
\hline & : 命名 & & $D^{*}$ & 28 & $\mathrm{D}$ & 3 \\
\hline \multicolumn{3}{|l|}{ 略名 } & C & 68 & $c$ & 18 \\
\hline \multicolumn{3}{|c|}{ 記号番号 } & $D$ & 38 & $D$ & 4 \\
\hline \multicolumn{3}{|c|}{ 外国商品名 } & $D$ & 31 & $D$ & 7 \\
\hline
\end{tabular}

耛 果

\section{1. 医来品名称に関する项目}

医薬品名称に関する情報項目の集計結果は表 1 亿示す ごとくで, 情報の必要度に関し,「商品名」,「一般名」, 「化学名」が高率を示しているのに対し，「命名法」 「記号番号」，「外国商品名」は $50 \%$ 以下を示してい る.

また情報の必要度が低率な項目では, 情報要求の頻度 む低率であることが認められるが，情報の必要度が高率 な項目, たと亲ば「化学名」では, 情報要求の頻度が低. いことを示しており, これは一般に薬剤師側の必要度が. 高いことを示しているものと思われる.

\section{2. 化合物の物理的, 化学的事項に関する项目}

化合物の物理的, 化学的事項に関する情報項目の集計 結果は表 2 に示すごとく, 化合物の物性, 試験法, 安定 性など大部分の項目で情報要求の頻度が低率であり，50 \%以上の施設でほとんど情報を要求されていないことを 示している. しかしこれらの項目の中で,「化合物の外 観」,「溶解性」, 「化学構造」,「分子式」では情報の. 必要度が $70 \%$ 以上の高率を示している.

「構造上関連ある化合物群」では, 情報の必要度が50 \%以下であるが, 情報の要求度は逆に $50 \%$ 以上を示し ている。また安定性」,「溶液の $\mathrm{pH}$ 及び溶液中で安 定であるpH限界」については，詳細な資料を必要とする 施設の多いことが認められる.

\section{3. 製剂に関する项目}

製剤に関する情報項目の集計結果は表 3 に示すごとく で,「散, 細粒, 顆粒などの 粒度分布」,「安息角, 飛散 性」については情報の必要度・要求度ともに $\mathbf{5 0} \%$ 以下

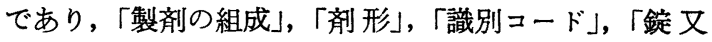
はカプセル剤の外観」で情報の必要度が $70 \%$ 以上を示 したにすぎない。

情報の必要度, 要求度ともに高率な項目は 「製剤の配合変化」で，それぞれ $96 \%, 84$ \%を示し，「軟育剤の稠度，展延性」，「坐 剂の軟化点, 溶解性などの物性」及び「期待 される追加剤形」は, 情報の必要度, 要求度 ともに $50 \%$ 以下である.

一方「注射剂の浸透圧比と溶血性」は, 情 報の要求度に比して必要度が高率を示してい る.

\section{4. 莱理に阁する情報顷目}

薬理に関する情報項目の集計結果は表 4 に 示すごとく,「作用発現時間」について，情報: の必要度が要求度よりはるかに高率を示し, 
表 2 化合物の物理的, 化学的事項に関する項目

\begin{tabular}{|c|c|c|c|c|c|c|}
\hline \multirow{2}{*}{ 項 } & \multicolumn{2}{|c|}{ 情報の必要度 } & \multicolumn{2}{|c|}{ 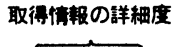 } & \multicolumn{2}{|c|}{ 情粐要求の频度 } \\
\hline & 必要度 & 不可欠\% & 必要度 & $\begin{array}{c}\text { 詳細资料 } \\
\text { 必要\% }\end{array}$ & 要求度 & 高频度\% \\
\hline 化合物の外観 & B & 79 & $C$ & 5 & C & 25 \\
\hline 化合物の溶解性 & B & 70 & $B$ & 11 & $D$ & 11 \\
\hline 化合物の融点 & $C^{*}$ & 50 & C & 4 & $D$ & 5 \\
\hline 化合物の分解点 & $D^{*}$ & 48 & C & 4 & D & 3 \\
\hline 化学椿造 & B & 84 & B & 5 & $D$ & 12 \\
\hline 分子式 & B & 71 & - & - & D & 11 \\
\hline 分子量 & $C^{*}$ & 54 & - & - & $D$ & 5 \\
\hline 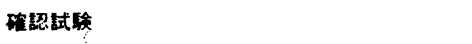 & C & 50 & C & 19 & $D$ & 3 \\
\hline 定国侙均 & $D^{*}$ & 37 & C & 18 & $D$ & 2 \\
\hline 原体の純度 & D & 46 & B & 9 & $D$ & 4 \\
\hline 原体の安定性 (温度・湿度・光) & B & 83 & A & 28 & C & 25 \\
\hline 原体溶液のp II 及ひ溶液中で安定である pH 限界 & B & 78 & B & 25 & D & 18 \\
\hline 柾造上関連ある化合物又は化合物群 & $D$ & 48 & B & 16 & C & 23 \\
\hline
\end{tabular}

表 3 製剈に関する項目

\begin{tabular}{|c|c|c|c|c|c|c|}
\hline \multirow{2}{*}{ 项目 } & \multicolumn{2}{|c|}{ 情辂の必要度 } & \multicolumn{2}{|c|}{ 取得得辄の眻細度 } & \multicolumn{2}{|c|}{ 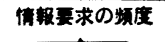 } \\
\hline & 必要度 & 不可欠纤 & 必要度 & 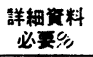 & 要求度 & 高频庭的 \\
\hline 制の組成：合量，倵形剂，添加剂，溶媒，溶解補助剂，基郕 & B & 89 & B & 23 & $\mathrm{C}$ & 24 \\
\hline 制上の特量 & C & 65 & B & 12 & C & 12 \\
\hline 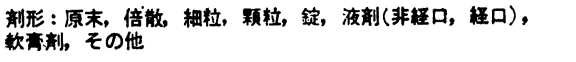 & B & 81 & - & - & C & 36 \\
\hline 散，湅粒，颗粒などの粒度分布 & $D^{*}$ & 25 & C & 5 & D & 3 \\
\hline 散，細粒，颗粒などの安息角, 飛散性などの物性 & D & 23 & c & 5 & D & 6 \\
\hline 钱別コード & B & 79 & - & - & C & 35 \\
\hline 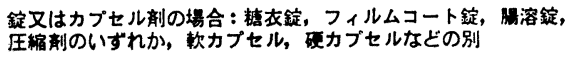 & B & 79 & - & - & C & 27 \\
\hline 錠又はカプセル剂の硬度, 崩填性などの物性 & C & 50 & C & 13 & D & 5 \\
\hline 錠又はカプセル刘の成分の溶出性 & C & 51 & B & 19 & $D$ & 8 \\
\hline 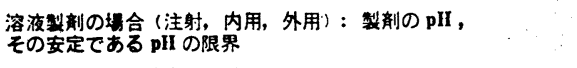 & B & 83 & B & 26 & C & 23 \\
\hline 注射刋の漫透圧比之溶血性 & B & 70 & B & 23 & D & 17 \\
\hline $\begin{array}{l}\text { バイフル中の活性成分の含量およひ溶解後の溶液の } \\
\text { 合計容量 }\end{array}$ & $C^{*}$ & 55 & C & 9 & $D$ & 10 \\
\hline 欶重绪の琱度，展延性などの物性 & $\mathrm{D}$ & 26 & C & 6 & $D$ & 14 \\
\hline 坐凨の靯化点，溶船性などの物性 & $D$ & 46 & C & 6 & D & 5 \\
\hline 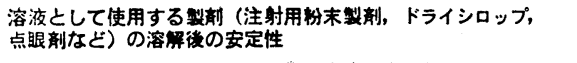 & A & 92 & c & 25 & c & 37 \\
\hline 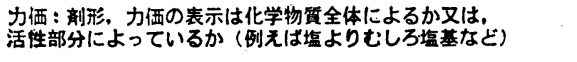 & C & 61 & C & 17 & D & 11 \\
\hline 期待される追加剂形 & $D$ & 11 & - & - & D & 1 \\
\hline 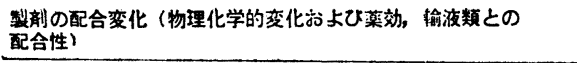 & A & 96 & B & 42 & B & 54 \\
\hline
\end{tabular}

「脳血液関門通過性」については，情報の必要度が $50 \%$ 以下と他にくらべて低率を示している.「催奇形性」,

「遣伝子変異性」が情報の必要度・要求度ともに高率を 示し,また「母乳中への移行率」「「排浛機構と排泄率」 では, 情報の必要度が要求度よりはるかに高率を示して いる.

なお，薬理に関する情報項目では，全般を通じ原著な
どの詳細な資料を必要とする施設の多いことが認められ る.

\section{5. 治康に圆する情報项目}

治療に関する情報項目の集計結果は表 5 に示すごとく で,「臨床比較試験の方法と効果判定」については, 情 報の必要度・要求度ともに低率を示し,「適応症」,「用 法・用量」,「副作用」,「中毒」,「使用上の注意」など, 
大部分の項目は必要度がきわめて高 率であり, 要求度も平行して高率を 示している.「食物による影䇾」，

「臨床検查値に対する影䇾」るまた 情報の要求度に比して必要度が高率 を示し,「禁忌症」「併用療法時の 注意」はそれぞれ情報の必要度・要 求度ともに $70 \%$ 以上を示している。

取得情報の詳細度については， 「副作用」「中毒」では 50\%以上が 詳細な資料を必要とし，そのほかの 項目でも詳細な資料を必要とする施 設が比較的多いことが認められる.

\section{6. 篦理に間する情報顷目}

管理に関する情報項目の集計結果 は表 6 に示すごとくで，「同一成分 薬」「同効薬」が情報の要求度で70 \%以上を示しているが，そのほかの 項目は低率である。

情報の必要度については,「法的
表 4 薬理に関する項目

\begin{tabular}{|c|c|c|c|c|c|c|}
\hline \multirow{2}{*}{ 项 } & \multicolumn{2}{|c|}{ 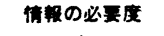 } & \multicolumn{2}{|c|}{ 取得倘机の样料度 } & \multicolumn{2}{|c|}{ 借隺要求の粉度 } \\
\hline & 必要度 & 不可欠位 & 必要度 & 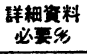 & 要求度 & 高䆩度里 \\
\hline 可理学的に閉尰ある化合物又は化合物群 & C & 61 & B & 17 & C & 24 \\
\hline 作用部位 & $\mathbf{B}$ & 85 & $\mathbf{B}$ & 34 & C & 23 \\
\hline 作用桠序 & B & 86 & $\mathbf{B}$ & 44 & C & 25 \\
\hline 吸収㛫所 & $\mathbf{B}$ & 90 & B & 33 & C & 22 \\
\hline 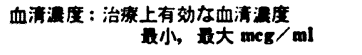 & B & 72 & B & 30 & C & 19 \\
\hline 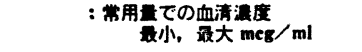 & C & 68 & B & 28 & c & 19 \\
\hline 作用吐现明間 & A & 90 & $\mathbf{B}$ & 32 & C & 23 \\
\hline 作用持落時間 & B & 81 & B & 29 & C & 22 \\
\hline 体組織への分布（钦物） & C & 66 & B & 31 & C & 11 \\
\hline 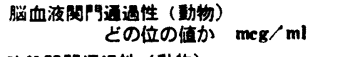 & $D$ & 47 & B & 25 & C & 7 \\
\hline 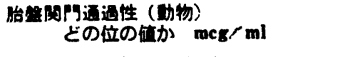 & C & 59 & B & 33 & $D$ & 13 \\
\hline 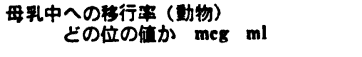 & B & 64 & B & 32 & $D$ & 14 \\
\hline 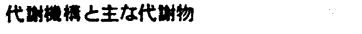 & C & 68 & B & 37 & D & 11 \\
\hline 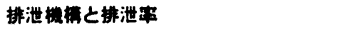 & $\mathbf{B}$ & 75 & B & 35 & $\mathrm{D}$ & 15 \\
\hline 志性海性（動物） & $\mathbf{B}$ & 89 & B & 33 & c & 22 \\
\hline 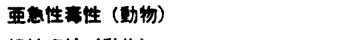 & B & 86 & $\mathrm{~B}$ & 31 & C & 19 \\
\hline 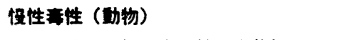 & B & 89 & $\mathrm{~B}$ & 33 & C & 23 \\
\hline 催倚形性，这伝子变暴性（動物） & A & 94 & B & 46 & $\mathbf{B}$ & 39 \\
\hline 抗感染敖 : その効果は殺菌的か静菌的か & B & 90 & B & 34 & C & 25 \\
\hline 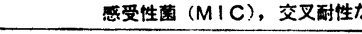 & ह゙ C & 53 & C & 21 & $D$ & 18 \\
\hline
\end{tabular}

表 5 治療飞関する項目

\begin{tabular}{|c|c|c|c|c|c|c|}
\hline \multirow{2}{*}{ 项 } & \multicolumn{2}{|c|}{ 情䢁の必要度 } & \multicolumn{2}{|c|}{ 取得得䢁の詳稩度 } & \multicolumn{2}{|c|}{ 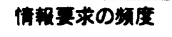 } \\
\hline & 必要度 & 不可久\% & 必要度 & $\begin{array}{l}\text { 詳細瓷料 } \\
\text { 必要\% } \\
\end{array}$ & 要求度 & 禹訝度％ \\
\hline 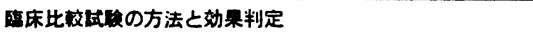 & $\mathrm{C}$ & 52 & B & 29 & D & 11 \\
\hline 道应症 & A & 94 & B & 25 & B & 52 \\
\hline 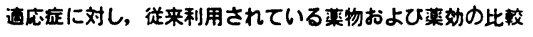 & B & 75 & B & 33 & $\mathbf{B}$ & 46 \\
\hline 遷用部位およひ必寅な注意 & A & 94 & B & 26 & $\mathbf{B}$ & 44 \\
\hline 用法（食前，食後，食成，時间每など） & A & 97 & B & 17 & $\mathbf{B}$ & 52 \\
\hline 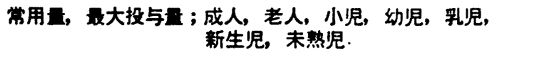 & B & 71 & $\mathbf{B}$ & 28 & B & 70 \\
\hline 1 回至, 1 日童, $\mathrm{mg} \mathrm{kg}, \mathrm{mg} \mathrm{m}^{2}$ & A & 97 & B & 19 & B & 67 \\
\hline 特別な投与法：1クール，日，退，月 & A & 92 & B & 26 & $\mathbf{B}$ & 39 \\
\hline 副作用（症状，频度，処雷法） & A & 100 & A & 59 & A & 74 \\
\hline 葙物アレルギーに対する注害事项 & A & 97 & B & 49 & $\mathbf{B}$ & 56 \\
\hline 中春（症状，拮抗玮，治嵰法） & A & 95 & $B$ & 51 & B & 43 \\
\hline 本制投与に当っての注意（使用上の注意を含む） & A & 99 & B & 41 & B & 54 \\
\hline 禁 忌 症 & A & 98 & B & 40 & B & 41 \\
\hline 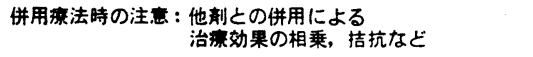 & A & 95 & A & 45 & B & 32 \\
\hline 食物による影慗 & $\mathrm{B}$ & 75 & B & 17 & C & 15 \\
\hline 臨床検查值に対する影響 & B & 74 & B & 32 & C & 21 \\
\hline
\end{tabular}

規制の有無」「有効期限」,「眝法」が $90 \%$ 以上,「会 社名」「包装」が $70 \%$ 以上の高率を示している。 また 「健保採否」についても同様に $70 \%$ 以上の高率を示し ている.

\section{7. 情報取得が困㔨な项目}

設問の「一般に取得困難な情報はどの項目ですか」に 対する集計結果は, 情報取得が困難な項目として 10 位 までを表 7 に示した．最も情報取得が困難であるとする 項目は，「食物による影響」であり，35\%の施設が情報 の取得が困難であるとしている.ついで「製凨の組成」 
表 6 管理に関する項目

\begin{tabular}{|c|c|c|c|c|c|c|}
\hline \multirow{2}{*}{ 项 } & \multicolumn{2}{|c|}{ 䩜辄の必要度 } & \multicolumn{2}{|c|}{ 取得倩䢁の鮮細度 } & \multicolumn{2}{|c|}{ 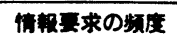 } \\
\hline & 必要度 & 不可欠\% & 必要度 & $\begin{array}{c}\text { 詳細许料 } \\
\text { 必要\% }\end{array}$ & 要求度 & 高频度\% \\
\hline 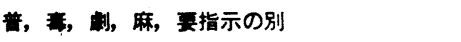 & A & 97 & - & - & C & 36 \\
\hline 有効期限：有無, 期限の指定 & A & 98 & B & 11 & C & 40 \\
\hline 法: 冷所, 暗所, 保存条件 & A & 99 & B & 13 & c & 40 \\
\hline 指定された眝法で 10\%力価減少を来たす時期 & C & 68 & B & 19 & D & 18 \\
\hline 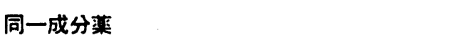 & $\mathbf{B}$ & 70 & - & - & B & 49 \\
\hline 同効藥 & B & 70 & - & - & $\mathbf{B}$ & 53 \\
\hline 造，睮入，责会社名 & B & 83 & - & - & C & 28 \\
\hline 包装 (形態, 規格, 包装記号) & B & 75 & - & - & C & 23 \\
\hline 踺保探否，薬価基隼価格 & $\mathbf{B}$ & 75 & - & - & C & 28 \\
\hline 無军年月日 & C & 61 & - & - & $D$ & 13 \\
\hline 許可年月日 & $D$ & 46 & - & - & D & 8 \\
\hline
\end{tabular}

表 7 情報取得が困難な項目

\begin{tabular}{|c|c|c|c|c|}
\hline 頉位 & 項 & $\mathscr{E}$ & 传報の必实度 & 情辄の要求度 \\
\hline 1 & 食物による影管 & 35 & B & $\mathrm{C}$ \\
\hline 2 & 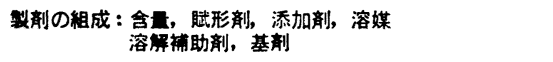 & 34 & B & C \\
\hline 3 & 外国商品名 & 33 & D & $D$ \\
\hline 3 & $\begin{array}{c}\text { 制刺の配合変化（物理化学的変化および } \\
\text { 楽勃, 輸液類との配合性） }\end{array}$ & 33 & A & B \\
\hline 3 & 胎艋関門通過性（助物）どの位の值か mcg. ml & 33 & C & $\mathrm{D}$ \\
\hline 3 & 母乳中への移行案（動物）どの位の值か $\mathrm{meg} \mathrm{ml}$ & 33 & B & D \\
\hline 3 & 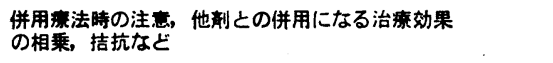 & 33 & A & B \\
\hline 4 & 指定された貼法で 10乡力価隇少を来たす時期 & 32 & C & $D$ \\
\hline 5 & 原体溶液の pH 及ひ溶液中で安定である pH 限界 & 28 & B & D \\
\hline 6 & 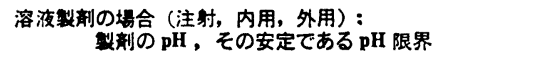 & 25 & $\mathbf{B}$ & C \\
\hline 6 & 注射制の漫透圧比と溶血性 & 25 & B & D \\
\hline 6 & 脳血液閥門通過性（動物）どの位の值か $\mathrm{mcg} . \mathrm{ml}$ & 25 & D & C \\
\hline 7 & 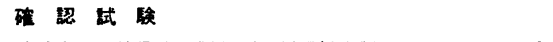 & 25 & C & D \\
\hline 7 & 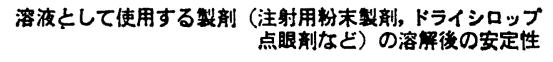 & 25 & A & C \\
\hline 8 & 催倚形性，运伝子変異性（動物） & 24 & A & B \\
\hline 9 & 定 旦 武 倹 & 23 & D & D \\
\hline 9 & 錠又はカブセル棛の成分の溶出性 & 23 & C & D \\
\hline 9 & 中策（症状，拮抗骫，治療法） & 23 & A & $\mathbf{B}$ \\
\hline 10 & 代射譏權と主な代期物 & 20 & C & D \\
\hline 10 & 剽作用（症状, 步度, 処溃法） & 20 & A & A \\
\hline
\end{tabular}

であるが，これは成分の含量に関する情報よりも, 賦形 斉, 添加剂, 溶媒, 溶解補助剂, 基剤に関し情報取得が 困難とするものと思われる.

これらの項目を情報の必要度と要求度に対比させてみ ると,「製凧の配合変化」「併用療法時の注意」は必要 度・要求度ともに $70 \%$ 以上を示し, 同様に「催奇形 性」「中毒」もそれぞれ必要度・要求度ともに $70 \%$ 以 上を示している. 「副作用」の項目においては, 情報の 必要度・要求度ともに $90 \%$ 以上の高率を示しており,
副作用情報を要求される頻度が高く，したがってその必 要度も高いにもかかわらず情報取得が困難とする施設が 20\%あることを示している.

\section{考寮}

この調查において医薬品に関する情報の必要度につい てみると, 総じて薬理, 治療, 管理に咸する情報項目の 必要度が高くあらわれており, 特に治療に関する情報項 目に対しては非常に高い結果となっている.これを情報 の要求度からみると, 治療に图する情報項目の要求度は 
高く, したがって情報の必要度も高い結果となってい” る.こうした関係は頻度はやや低くなるが, 薬理, 管理 についても認められる. しかし製剤に関する情報項目 之, 化合物の物理的化学的事項に夙する情報項目では必 要度に対するほどに情報の要求度はない傾向を示してお ク，これは主として楽剤師側にとって必要な情報である と思われる.

この調査において設定した情報項目のなかで，すべて の施設が全く不要とする項目はなく, また追加すべき項 目として「各社別製偊一覧表（実物写真つき）」,「薬理 実験文献の所在」,「臨床試験文献の入手方法又は検索方 法」,「小児, 新生児, 未熟児」,「製造年月日」,「カプセ ル又は錠剤の識別」が挙げられている.

医薬品情報の収集に関して, R. C. Bogash'1) が病院 薬局における医薬品の多種多様な情報を収集, 整理, 利 用に便ならしめるために, New Products Information and Interview Formを提案している. また米国病院薬 阂師会は薬事委員会での医薬品検討材料としたり，ある いは病院医薬品集に新たに収載するために，医薬品の情 報を収集する目的で, Drug Product Information Form を作成している2).

福室 ${ }^{3)}$ は, 米国病院薬剤師会のフォームを用いて, 新 製品 17 品目についてどの程度の情報が得られるかを調 查したところ, 17 品目の質問項目数 662 項目のうち, 情報の得られた項目は 357 項目で, 全体としての情報取 得率は $53.9 \%$ であった.

米国病院薬㶡師会の Drug Product Information Fo$\mathrm{rm}$ を基礎に, 東京都病院薬剤師会において新製品イン タビューフォームが検討され，その利点として次の 9 項 を挙げている4).

1）医薬品に必要な情報の全ての項目が配列してあり， したがって思いつきで情報を得たり得なかったりといら ことがない.

2）口頭による伝達は後日忘れてしまい思い出すのが困 難であるが，このフォームにより不確かな記憶から確実 な情報を蘇らせることができる゙。

3）常に同じ質問をすることになるので, 製品相互の比 較評価が容易となる。

4 ）新製品が紹介される時，その任にある薬剤師に限ら ず，応接できる薬剤師誰でもがこのフォームによって説 明を聞くことができるので，特定の薬剤師のみ新製品紹 介のために時間を費すことがなくなる。

5 ) 製薬会社のディテイルマンに情報源としての役割を 与えることになる.

6 ）パソチカードの原情報として利用できる.
7）このフォームだけでも簡単な抄録資料としての性格 を備えており, 至急の場合の参考資料として利用でき る.

8）医薬品集の編さんに役立つ.

9) 医・薬学生, 医師, 薬剤師, 看護婦の医薬品教育の 教材として利用することができる.

この新製品インタビューフォームの最終案は昭和 45 年 に提案され, 検討の結果盛り込まれた医薬品情報の項目 は米国病院薬剤師会のフォームより詳細になってい る.

福室6)は,この新しいフォームを用いて新製品 20 品 目の情報取得について調查した結果, およそ $58 \%$ 程度 の情報しか得られなかった。このらち情報取得が困難な 項目は,「胎盤関門の通過性」,「孚汁中への移行」,「中 毒の症状, 拮抗剤, 治療法」,「薬物相互作用」, 「配合変 化」,「臨床実験による有效性」,「血清濃度」,「解毒 : 排 泄，代謝産物」，「製剤の安定性」についてである.これ らの結果に見られることは, 医薬品カタログに記されて いるような医薬品の一般的な事項に対しては容易に情報 が得られるが, 薬物の生体内挙動や薬物相互作用, 安定 性, 配合変化など, 薬理学, 薬剤学, 治療学上の重要な 情報が得難いことを示している. 今回行なった調査にお いてもよく似た傾向を示していることは，現在において もなおあまり変わっていないといえよう。

この調査における医薬品情報の要求度は, 病院薬局の 立場からみたもので，医師の側に拈けるそれについて， 最近東京女子医大の医師 215 名に対して行なった小清水 の報告7)によれば, 医師の関心が高い医薬品情報とし $\tau$, 副作用情報 $30.8 \%$, 新薬・治験薬 $25.8 \%$, 薬物相 互作用 $19.9 \%$, 院内採用 新薬 $8.7 \%$, 厚生省通達事項 $2.5 \%$ の順となっており, 半数以上の医師が副作用や薬 物相互作用に関心を持っており，それだけ安全性に対す る意識が強いとし, 実際に薬物療法上重要な情報として 挙げられたものは, 副作用 $30.2 \%$, 楽効 $27.7 \%$, 作用 機序 $17.1 \%$, 用法用量 $16.7 \%$, 使用上の注意 $6.7 \%$, 組成 $0.8 \%$, 剂形 $0.8 \%$ となっている.

また医薬品の情報源としては，医学書・専門誌 28.2 $\%$, 他の医師 $19.1 \%$, 添付文書 (能書) $18.7 \%$, 製薬 会社のプロパーや宣伝物など $18.2 \%$, 学会・研究会 $11.6 \%$, 薬剤師からの情報 $3.7 \%$ と報告している.

大阪大学病院の医師 126名について調査した浜らの報 告8) では，新薬に関する情報源として重視する情報は， 薬の評価や副作用に関する参考書(たとえば AMA Drug Evaluations, PDR など) $51.8 \%$, 医学雑誌の論文 43 . $6 \%$, 薬剤部薬品情報室 $39.1 \%$, 医師の 評判 $37.1 \%$, 
処方参考書, 添付文書, 教科畵, 病院医薬品集の順であ る. それに対し実際に利用する頻度の高いものとして は, 病院医薬品集 $49.5 \%$, 他の医師の評価や説明 48.6 $\%$, 処方参考書 $36 \%$, 添付文書, 薬剤部薬品 情報室, 副作用参考書の順となっている. 製薬会社のプロパーか らの情報は重視も利用もあまりされておらず，添付文畫 は重視の程度も利用度も中間に位置していることは1つ の特徵であると述へ，医師の情報の取得に対する態度は より手軽な，それでいてある程度は客観的な情報が実際 には利用される頻度が高く, 情報の利用の仕方にはやや 安易な傾向が見られると報告している.

一方米国に拈ける医師の情報源と利用度については， FDA が臨床医約 19,000人を対象として調查を行ない9， その中で医師が求める情報の種類として，PDR を情報 源として, 作用, 投与量, 成分, 副作用, 相互作用, 能 書を情報源として, 投与量, 成分, 副作用, 相互作用, FDA Drug Bulletin を情報源として, 作用, 副作用, プロパーからは価格の情報を得るとなっている．また医 師が利用する情報源のらち利用度の高いものとして, J. Am. Med. Assoc. は定期刊行誌の中で利用率が最も高 い. PDR 約 $97 \%$, FDA Drug Bulletin 約 $88 \%$, 能書 約 $83 \%$ ，仲間の医師約 $74 \%$, Medical letter 約 $65 \%$, コンサルタント約 $65 \%$ ，プロパーからの資料約 $64 \%$, プロパーの説明約 $61 \%$ (開業医の利用度が高い), 雑誌 広告約 $50 \%$ となっており，それぞれ情報源として利用 されていると報告している.

わが国で昭和 49 年に日本製薬工業協会が行なった医

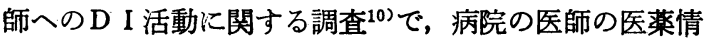
報の入手経路についてみると，1位は製薬会社のプロパ 一，2 位は医薬品パンフレット・文献集，3位は医学専 門誌の記事, 以下学会発表や学会誌, 医師間の情報, 学 術講演会・研究会, 医学専門誌の広告, 製薬会社のダイ レクトメール，外国文献の順で，病院薬局から情報を入 手するというむのはわずか $12 \%$ である. また医薬品の 安全性, 副作用, 薬効などについての情報入手経路につ いては, 1 位は医学専門誌の記事, 2 位は学会発表や学 会誌, 3 位は製薬会社のプロパー, 以下医師間の情報, 医薬品パンフレット・文献集, 学術講演会・研究会, 添 付文書の順となって扣り，ここでも病院薬剈部（薬局） から情報を入手するといらのはわずか $5 \%$ である．日本
製薬工業協会の調査では，プロパーの情報源としての利 用度が高いが，この点は東京女子医大，大阪大学の傾向 と異なっている.

医薬品情報に関する医師側の状況は以上述べたごとく であるが，今回の調査に扩る病院診療所の薬剤師が感 している情報の必要度は，医師が必要とする情報は薬剤 師にとっても必要な情報となっており，そのほかに薬剤 師独自の立場で医薬品の品質確保, 管理上のために必要 な情報が加わっている。

医薬品情報の詳細度については，大部分が要約情報て 可としていることは，情報提供に際し多くの場合要約 情報として提供するためと思われる．しかし本来は原情 報を得，その中から客観性の高い情報を選び，次に要約 情報を作成するのが一般的であり，最初から要約情報を 要望することは情報の評価を誤まる結果ともなりかねな い．たしかに医薬品に関する情報量の莫大なこと，及び 情報の多様性を考えると止むを得ない場合が多いことは 了承できるが，反面ここに薬剤師側の情報取得に対する やや安易な傾向があるように思われる.

この調查で設定した医薬品情報項目により質的にも量 的にも満足できる情報の収集を行うとともに，これをも とに病院・診療所の薬局が医薬品に関する重要な情報源 として機能すべきであると思われる.

謝辟 本稿を終るにあたり，フンケート調査にで協力い ただいた各施設に深く感謝致します。

\section{文 解}

1) R. C. Bogsh : Am. J. Hosp. Pharm., 20, 253 -254(1963).

2) M. J. Reilly : Ibid., 25, 587-589 (1968).

3）福室赛治：薬局，21，39-42 (1970).

4）福室憲治：東京都病院薬郕師会会報，28 (2), 10 -11 (1969).

5) 高橋則行 : Ibid., 31 (2), 16-18 (1970).

6）福室憲治：ファルマシア，6，691—693 (1971).

7）小清水敏昌：第 5 回 日本病院薬剂師会 関東学術 大会講演要旨集（1975．群馬）140-141，薬事日 報，第 5268号 (1975.9.16).

8）浜六郎，小塚雄民，高杉益充，村田三郎，日山興 彦：医学のあゆみ, 86 (7), 403-409 (1973).

9) J. Am. Med. Assoc., 229 (10), 1336-1338, Sep. 2 (1974).

10）医師への D I 活動関する調查：日本製薬工業協 会 (1975. 12). 